\title{
Chemical, biochemical and electrochemical assays to evaluate phytochemicals and antioxidant activity of wild plants
}

\author{
Lillian Barros, Luis Cabrita, Miguel Vilas Boas, Ana Maria Carvalho, Isabel C.F.R. Ferreira* \\ CIMO/Escola Superior Agrária, Instituto Politécnico de Bragança, Campus de Santa Apolónia, Apartado 1 172, 5301 -855 Bragança, Portugal
}

\section{A R T I C L E I N F O}

\section{Article history:}

Received 19 November 2010

Received in revised form 2 February 2011

Accepted 6 February 2011

Available online 2 March 2011

\section{Keywords:}

Cytisus multiflorus

Filipendula ulmaria

Sambucus nigra

Antioxidants

Phytochemicals

Chromatography

Electrochemistry

\begin{abstract}
A B S T R A C T
Plants are a source of compounds that may be used as pharmacologically active products. Cytisus multiflorus, Filipendula ulmaria and Sambucus nigra have been used as important medicinal plants in the Iberian Peninsula for many years, and are claimed to have various health benefits. Herein, the phytochemical composition and antioxidant activity of the mentioned wild medicinal plants were evaluated in vitro, based on chemical, biochemical and electrochemical methods. F. ulmaria was found to be richest in antioxidant phytochemicals, such as phenolics (228 mg GAE/g DW), flavonoids (62 mg CE/g DW), ascorbic acid $(2700 \mu \mathrm{g} / \mathrm{g} \mathrm{DW})$ and tocopherols $(497 \mu \mathrm{g} / \mathrm{g} \mathrm{DW})$. The antioxidant activity was found to vary in the order: F. ulmaria $>$ S. nigra $>$ C. multiflorus, irrespective of the analysis method. Electrochemical methods have proven to be rapid and inexpensive techniques to characterise the antioxidant activity of plant extracts.
\end{abstract}

(c) 2011 Elsevier Ltd. All rights reserved.

\section{Introduction}

Reactive oxygen species (ROS) such as the superoxide anion, hydrogen peroxide, hydroxyl, acyl and alkyloxy radicals are highly reactive species that are responsible for many cell disorders through their action on proteins, lipids and DNA. Along with other pro-oxidants, such as $\mathrm{Cu}$ and Fe ions, ROS act by modifying the oxidative balance within cells and thus are important mediators of cell injuries. They are assumed to play an important role in the development of many diseases, such as atherosclerosis, reperfusion injury, cataractogenesis, rheumatoid arthritis, inflammatory disorders, cancer and the ageing process itself (Gutteridge \& Halliwell, 2000; Halliwell, 1996; Valko et al., 2007). Natural antioxidants protect the human body from free radicals, prevent oxidative stress and associated diseases (Ferreira, Barros, \& Abreu, 2009; López et al., 2007). For these reasons they play a very important role in health care. Plants are a source of compounds with antioxidant activity such as phenolic acids, flavonoids (including anthocyanins and tannins), vitamins and carotenoids that may be used as pharmacologically active products (López et al., 2007).

Widespread empirical use of wild plants demands accurate and reliable information on their phytochemicals and antioxidant activity, as well as on the potential benefits and prospective products, such as nutraceuticals and phytomedicines. This is the case of three species that have long been used in the Iberian Peninsula as

\footnotetext{
* Corresponding author. Tel.: +351 273 303219; fax: +351 273325405 .

E-mail address: iferreira@ipb.pt (I.C.F.R. Ferreira).
}

important medicinal plants and less often as food or food additives. Cytisus multiflorus (L'Hér.) Sweet (Fabaceae, white Spanish broom; port: giesta branca) which is native to the Iberian Peninsula; Filipendula ulmaria (L.) Maxim. (Rosaceae, meadowsweet; port: rainha-dos-prados) and Sambucus nigra L. (Adoxaceae, elder; port: sabugueiro), are native throughout most of Europe and Asia. Besides the symbolic and aesthetic value of their whitish flowers, they have been regarded as powerful ingredients for homemade remedies mainly due to their anti-inflammatory, diuretic and diaphoretic properties, traditionally recognised by healers and consumers. A sweet tea is made from the dried flowers of meadowsweet; elderflowers are eaten raw or cooked and are used to prepare syrups (Camejo-Rodrigues, Ascensão, Bonet, \& Vallès, 2003; Carvalho, 2010; Pardo de Santayana, 2007, 2008).

These plants represent a source of natural antioxidants that might serve as leads for the development of novel drugs. In fact, several anti-inflammatory, digestive, antinecrotic, neuroprotective, and hepatoprotective drugs have recently been shown to act through an antioxidant and/or radical-scavenging mechanism as part of their activity (Conforti et al., 2008). Furthermore, some drugs have various and severe adverse effects. Therefore, products of natural origin with no or very few side effects are desirable as substitutes for chemical therapeutics.

Numerous tests have been developed for measuring the antioxidant capacity of food and biological samples. However, there is no universal method that can measure the antioxidant capacity of all samples accurately and quantitatively (Frankel \& Finley, 2008; Prior, Wu, \& Schaich, 2005). With respect to electrochemical 
methods, there has been considerable work done on characterising the behaviour of isolated natural products. In particular, voltammetric methods represent an attractive option for rapid screening of large numbers of plant samples in the search for novel antioxidants. However, the technique has not yet found widespread use, when compared to established methods, such as the DPPH and Folin-Ciocalteu assays. In fact, there are limited references on the application of voltammetric techniques on plant or algae extracts, juices, tea and wine, with the aim of assessing their total antioxidant activity (Chevion, Chevion, Chock, \& Beecher 1999; Kilmartin, Zou, \& Waterhouse, 2001; Litescu \& Radu, 2000).

Herein the antioxidant capacity of these three wild medicinal plants was evaluated by radical-scavenging activity and lipid peroxidation inhibition, using in vitro assays. Electrochemical techniques, such as cyclic voltammetry and differential pulse voltammetry were also used, to provide a further insight into redox-processes within plant extracts. These techniques have been tested and developed as an alternative and/or complementary tool for the evaluation of antioxidant activity, expressed in terms of "antioxidant power", due to their quickness, simplicity and low cost (Barros et al., 2008; Blasco, Rogerio, González, \& Escarpa, 2005; Cosio, Buratti, Mannino, \& Benedetti, 2006). The aim of this study was to obtain a complete characterisation of the antioxidant properties of flowers of Spanish broom, meadowsweet and elder, and their chemical composition in phytochemicals and antioxidants, such as vitamins, pigments, sugars, fatty acids, phenolics and flavonoids.

\section{Materials and methods}

\subsection{Samples}

Inflorescences of the three species, with flowers fully open and functional, were collected in May 2009, in the Natural Park of Montesinho, Trás-os-Montes, north-eastern Portugal, considering the Portuguese folk pharmacopeia and the local medicinal uses. Voucher specimens were deposited in the Herbário da Escola Superior Agrária de Bragança (BRESA). Samples were lyophilised (Ly-8FM-ULE, Snijders Scientific B.V., Tilburg, The Netherlands) and stored at $-20^{\circ} \mathrm{C}$ for subsequent analysis.

\subsection{Standards and reagents}

Acetonitrile $99.9 \%, n$-hexane $95 \%$, ethyl acetate $99.8 \%$ and methanol were of HPLC grade from Lab-Scan (Lisbon, Portugal). The fatty acid methyl ester (FAME) reference standard mixture 37 (standard 47885-U) was purchased from Sigma (St. Louis, MO), as were other individual fatty acid isomers, L-ascorbic acid, tocopherols and sugars standards, Trolox (6-hydroxy-2,5,7,8-tetramethylchroman-2-carboxylic acid), gallic acid and (+)-catechin. Racemic tocol $50 \mathrm{mg} / \mathrm{mL}$, was purchased from Matreya LLC (Pleasant Gap, PA). 2,2-Diphenyl-1-picrylhydrazyl (DPPH) was obtained from Alfa Aesar (Ward Hill, MA). Sodium perchlorate monohydrate, purity grade, was purchased from Fluka (Buchs, Switzerland), and was dried overnight at $30^{\circ} \mathrm{C}$ before use. All other chemicals and solvents were of analytical grade and purchased from chemical suppliers. Ultra-pure water was obtained from a Milli-Q water purification system (TGI Pure Water Systems; IsoPure Water, Santa Ana, CA).

\subsection{Phytochemicals and antioxidants}

\subsubsection{Determination of tocopherols}

BHT solution in hexane $(10 \mathrm{mg} / \mathrm{mL}, 100 \mu \mathrm{l})$ and tocol solution in hexane (internal standard; $50 \mu \mathrm{g} / \mathrm{mL}, 400 \mu \mathrm{l}$ ) were added to the sample prior to the extraction procedure. The samples ( $500 \mathrm{mg}$ ) were homogenised with methanol $(4 \mathrm{~mL})$ by vortex mixing (1 min). Subsequently, hexane $(4 \mathrm{~mL})$ was added and again vortex mixed for $1 \mathrm{~min}$. After that, saturated $\mathrm{NaCl}$ aqueous solution $(2 \mathrm{~mL}$ ) was added, the mixture was homogenised $(1 \mathrm{~min})$, centrifuged (Centurion K240R refrigerated centrifuge, 5 min, 4000g; Centurion Scientific Ltd., Stoughton, UK) and the clear upper layer was carefully transferred to a vial. The sample was re-extracted twice with hexane. The combined extracts were taken to dryness under a nitrogen stream, redissolved in $2 \mathrm{~mL}$ of $n$-hexane, dehydrated with anhydrous sodium sulphate, filtered through $0.2-\mu$ m nylon filters from Whatman, transferred into a dark injection vial and analysed by HPLC. The equipment consisted of an integrated system with a pump (Knauer, Smartline system 1000; Knauer, Berlin), degasser system (Smartline Manager 5000), auto-sampler (AS-2057 Jasco, Tokyo, Japan) and a fluorescence detector (FP-2020; Jasco) with 290 and $330 \mathrm{~nm}$ as excitation and emission wavelengths, respectively. Data were analysed using Clarity 2.4 Software (DataApex, Prague, Czech Republic). The chromatographic separation was achieved with a Polyamide II $(250 \times 4.6 \mathrm{~mm})$ normal-phase column from YMC (Waters, Milford, MA) operating at $30^{\circ} \mathrm{C}$. The mobile phase used was a mixture of $n$-hexane and ethyl acetate (70:30, v/v) at a flow rate of $1 \mathrm{~mL} / \mathrm{min}$, and the injection volume was $20 \mu \mathrm{l}$. The compounds were identified by chromatographic comparisons with authentic standards. Quantification was based on the fluorescence signal response, using the internal standard method. Tocopherol contents in the samples are expressed in $\mu \mathrm{g}$ per g of dry sample (DW).

\subsubsection{Determination of ascorbic acid}

A fine powder (20 mesh) of sample (500 mg) was extracted with metaphosphoric acid $(1 \%, 10 \mathrm{~mL})$ for $45 \mathrm{~min}$ at room temperature and filtered through Whatman N4 filter paper. The filtrate $(1 \mathrm{~mL})$ was mixed with 2,6-dichloroindophenol $(9 \mathrm{~mL})$ and the absorbance was measured after $30 \mathrm{~min}$ at $515 \mathrm{~nm}$ against a blank (Analytik Jena 200-2004 spectrophotometer; Analytik Jena, Jena, Germany). Content of ascorbic acid was calculated on the basis of the calibration curve of authentic L-ascorbic acid $\left(6.0 \times 10^{-3}\right.$ $\left.1.0 \times 10^{-1} \mathrm{mg} / \mathrm{mL}\right)$, and the results were expressed as $\mathrm{mg}$ per $100 \mathrm{~g} \mathrm{DW}$.

\subsubsection{Determination of lipid-soluble pigments}

A fine dried powder $(150 \mathrm{mg})$ was vigorously shaken with $10 \mathrm{~mL}$ of acetone-hexane mixture (4:6) for $1 \mathrm{~min}$ and filtered through Whatman No. 4 filter paper. The absorbance of the filtrate was measured at 453, 505, 645 and $663 \mathrm{~nm}$. Content of $\beta$-carotene was calculated according to the following equation:

$$
\begin{aligned}
& \beta \text {-carotene }(\mathrm{mg} / 100 \mathrm{~mL})=0.216 \times A_{663}-1.220 \times A_{645}-0.304 \\
& \times A_{505}+0.452 \times A_{453} ; \\
& \text { Lycopene }(\mathrm{mg} / 100 \mathrm{~mL})=-0.0458 \times A_{663}+0.204 \times A_{645}-0.304 \\
& \times A_{505}+0.452 \times A_{453} ; \\
& \text { Chlorophyll a }(\mathrm{mg} / 100 \mathrm{~mL})=0.999 \times A_{663}-0.0989 \times A_{645} ; \\
& \text { Chlorophyll } \mathrm{b}(\mathrm{mg} / 100 \mathrm{~mL})=-0.328 \times A_{663}+1.77 \times A_{645} \text {, and } \\
& \text { further expressed in } \mu \mathrm{g} \text { per g dry weight }(\mathrm{dw}) .
\end{aligned}
$$

\subsubsection{Determination of sugars}

Dried sample powder ( $1.0 \mathrm{~g}$ ) was spiked with melezitose (IS, $5 \mathrm{mg} / \mathrm{mL}$ ), and was extracted with $40 \mathrm{~mL}$ of $80 \%$ aqueous ethanol at $80^{\circ} \mathrm{C}$ for $30 \mathrm{~min}$. The resulting suspension was centrifuged at $15,000 \mathrm{~g}$ for $10 \mathrm{~min}$. The supernatant was concentrated at $60^{\circ} \mathrm{C}$ under reduced pressure and defatted three times with $10 \mathrm{~mL}$ of ethyl ether. After concentration at $40^{\circ} \mathrm{C}$, the solid residues were dissolved in water to a final volume of $5 \mathrm{~mL}$ and filtered through $0.2-\mu \mathrm{m}$ nylon filters from Whatman (Maidstone, UK). Soluble sugars were determined by HPLC coupled to a refraction index 
(RI) detector (Knauer Smartline 2300). The chromatographic separation was achieved with a Eurospher 100-5 $\mathrm{NH}_{2}$ column $\left(4.6 \times 250 \mathrm{~mm}, 5 \mu \mathrm{m}\right.$, Knauer) operating at $30^{\circ} \mathrm{C}$. The mobile phase was acetonitrile/deionised water, 7:3 (v/v) at a flow rate of $1.0 \mathrm{~mL} / \mathrm{min}$. Sugar identification was made by comparing the relative retention times of sample peaks with standards. Quantification was made by internal normalisation of the chromatographic peak area and the results are expressed in mg per $\mathrm{g}$ DW.

\subsubsection{Determination of fatty acids}

Fatty acids (obtained after Soxhlet extraction) were methylated with $5 \mathrm{~mL}$ of methanol:sulphuric acid:toluene 2:1:1 (v:v), for at least $12 \mathrm{~h}$ in a stirrer bath at $50^{\circ} \mathrm{C}$ and $160 \mathrm{rpm}$; then $3 \mathrm{~mL}$ of deionised water were added, to obtain phase separation; the FAME were recovered with $3 \mathrm{~mL}$ of diethyl ether by shaking in a vortex, and the upper phase was passed through a micro-column of anhydrous sodium sulphate, in order to eliminate the water; the sample was recovered in a Teflon vial, and before injection the sample was filtered with a $0.2-\mu \mathrm{m}$ nylon filter from Whatman. The fatty acid profile was analysed with a DANI Model 1000 gas chromatograph (DANI Instruments S.p.A, Cologno Monzese, Italy) equipped with a split/splitless injector, a flame ionisation detector (FID) and a Macherey-Nagel column $(30 \mathrm{~m} \times 0.32 \mathrm{~mm}$ ID $\times 0.25 \mu \mathrm{m}$ film thickness; Macherey-Nagel GmbH \& Co. KG, Düren, Germany). The oven temperature program was as follows: the initial temperature of the column was $50^{\circ} \mathrm{C}$, held for $2 \mathrm{~min}$, then a $10^{\circ} \mathrm{C} / \mathrm{min}$ ramp to $240^{\circ} \mathrm{C}$ and held for $11 \mathrm{~min}$. The carrier gas (hydrogen) flow-rate was $4.0 \mathrm{~mL} / \mathrm{min}$ ( $0.61 \mathrm{bar})$, measured at $50^{\circ} \mathrm{C}$. Split injection (40:1) was carried out at $250^{\circ} \mathrm{C}$. For each analysis $1 \mu \mathrm{l}$ of the sample was injected onto the GC. Fatty acid identification was made by comparing the relative retention times of FAME peaks from samples with standards. The results were recorded and processed using CSW 1.7 software (DataApex 1.7) and expressed in relative percentage of each fatty acid.

\subsubsection{Determination of phenolics}

A fine dried powder (20 mesh; $\sim 1 \mathrm{~g}$ ) was stirred with $50 \mathrm{~mL}$ of methanol at $25^{\circ} \mathrm{C}$ and $150 \mathrm{rpm}$ for $1 \mathrm{~h}$ and filtered through Whatman No. 4 paper. The residue was then extracted with one additional $50-\mathrm{mL}$ portion of methanol. The combined methanolic extracts were evaporated at $35^{\circ} \mathrm{C}$ under reduced pressure, redissolved in methanol at $20 \mathrm{mg} / \mathrm{mL}$ (stock solution), and stored at $4{ }^{\circ} \mathrm{C}$ for further use. For phenolics determination, an aliquot of the extract solution $(0.125 \mathrm{mg} / \mathrm{mL} ; 1 \mathrm{~mL})$ was mixed with FolinCiocalteu reagent $(5 \mathrm{~mL}$, previously diluted with water $1: 10 \mathrm{v} / \mathrm{v}$ ) and sodium carbonate $(75 \mathrm{~g} / \mathrm{L}, 4 \mathrm{~mL})$. The tubes were vortexed for $15 \mathrm{~s}$ and allowed to stand for $30 \mathrm{~min}$ at $40^{\circ} \mathrm{C}$ for colour development. Absorbance was then measured at $765 \mathrm{~nm}$. Gallic acid was used to calculate the standard curve $\left(9.4 \times 10^{-3}-1.5 \times 10^{-1} \mathrm{mg} /\right.$ $\mathrm{mL}$ ), and the results were expressed as $\mathrm{mg}$ of gallic acid equivalents (GAE) per g DW.

\subsubsection{Determination of flavonoids}

For flavonoids, an aliquot of the extract solution $(0.125 \mathrm{mg} / \mathrm{mL}$; $0.5 \mathrm{~mL}$ ) was mixed with distiled water $(2 \mathrm{~mL})$ and subsequently with $\mathrm{NaNO}_{2}$ solution $(5 \%, 0.15 \mathrm{~mL})$. After $6 \mathrm{~min}, \mathrm{AlCl}_{3}$ solution $(10 \%, 0.15 \mathrm{~mL})$ was added and allowed to stand for a further $6 \mathrm{~min}$; thereafter, $\mathrm{NaOH}$ solution $(4 \%, 2 \mathrm{~mL})$ was added to the mixture. Immediately, distiled water was added to bring the final volume to $5 \mathrm{~mL}$. Then the mixture was properly mixed and allowed to stand for $15 \mathrm{~min}$. The intensity of pink colour was measured at $510 \mathrm{~nm}$. (+)-Catechin was used to calculate the standard curve $\left(4.5 \times 10^{-3}-2.9 \times 10^{-1} \mathrm{mg} / \mathrm{mL}\right)$ and the results were expressed as $\mathrm{mg}$ of $(+)$-catechin equivalents (CE) per $\mathrm{g}$ DW.

\subsection{Chemical and biochemical assays to evaluate antioxidant activity}

\subsubsection{DPPH radical-scavenging activity}

The reaction mixture in each one of the 96 wells (ELX800 microplate reader; BioTek, Winooski, VT) consisted of one of the different concentrations of the extracts $(0.03-1.00 \mathrm{mg} / \mathrm{mL} ; 30 \mu \mathrm{l})$ and aqueous methanolic solution $(80: 20 \mathrm{v} / \mathrm{v}, 270 \mu \mathrm{l})$ containing DPPH radicals $\left(6 \times 10^{-5} \mathrm{M}\right)$. The mixture was left to stand for $60 \mathrm{~min}$ in the dark. The reduction of the DPPH radical was determined by measuring the absorption at $515 \mathrm{~nm}$. The radical-scavenging activity (RSA) was calculated as a percentage of DPPH discolouration using the equation:

$$
\% R S A=\left[\left(A_{\mathrm{DPPH}}-A_{\mathrm{S}}\right) / A_{\mathrm{DPPH}}\right] \times 100,
$$

where $A_{\mathrm{S}}$ is the absorbance of the solution when the sample extract has been added at a particular level, and $A_{\mathrm{DPPH}}$ is the absorbance of the DPPH solution. The extract concentration providing $50 \%$ of radical-scavenging activity $\left(E C_{50}\right)$ was calculated from the graph of RSA percentage against extract concentration. Trolox was used as standard.

\subsubsection{Reducing power}

The different concentrations of the extracts $(0.03-1.00 \mathrm{mg} / \mathrm{mL}$; $0.5 \mathrm{~mL}$ ) were mixed with sodium phosphate buffer $(200 \mathrm{mmol} / \mathrm{L}$, $\mathrm{pH} 6.6,0.5 \mathrm{~mL})$ and potassium ferricyanide $(1 \% \mathrm{w} / \mathrm{v}, 0.5 \mathrm{~mL})$. The mixture was incubated at $50{ }^{\circ} \mathrm{C}$ for $20 \mathrm{~min}$, and trichloroacetic acid $(10 \% \mathrm{w} / \mathrm{v}, 0.5 \mathrm{~mL})$ was added. The mixture $(0.8 \mathrm{~mL})$ was transferred to 48 -well plates, and deionised water $(0.8 \mathrm{~mL})$ and ferric chloride $(0.1 \% \mathrm{w} / \mathrm{v}, 0.16 \mathrm{~mL})$ were added. The absorbance was measured at $690 \mathrm{~nm}$ in the microplate reader mentioned above. The extract concentration providing 0.5 of absorbance $\left(E C_{50}\right)$ was calculated from the graph of absorbance at $690 \mathrm{~nm}$ against extract concentration. Trolox was used as standard.

\subsubsection{Inhibition of -carotene bleaching}

A solution of $\beta$-carotene was prepared by dissolving $\beta$-carotene $(2 \mathrm{mg})$ in chloroform $(10 \mathrm{~mL})$. Two millilitres of this solution were pipetted into a round-bottomed flask. After the chloroform was removed at $40{ }^{\circ} \mathrm{C}$ under vacuum, linoleic acid $(40 \mathrm{mg})$, Tween 80 emulsifier $(400 \mathrm{mg})$, and distiled water $(100 \mathrm{~mL})$ were added to the flask with vigorous shaking. Aliquots $(4.8 \mathrm{~mL})$ of this emulsion were transferred into different test tubes containing different concentrations of the extracts $(0.03-1.00 \mathrm{mg} / \mathrm{mL} ; 0.2 \mathrm{~mL})$. The tubes were shaken and incubated at $50{ }^{\circ} \mathrm{C}$ in a water bath. As soon as the emulsion was added to each tube, the zero time absorbance was measured at $470 \mathrm{~nm}$ using a spectrophotometer. A blank devoid of $\beta$-carotene, was prepared for background subtraction. $\beta$-Carotene bleaching inhibition was calculated using the following equation:

$\beta$-carotene bleaching inhibition $=(\beta$-carotene content after 2 hof assay/initial $\beta$-carotene content) $\times 100$.

The extract concentration providing 50\% antioxidant activity $\left(E C_{50}\right)$ was calculated by interpolation from the graph of $\beta$-carotene bleaching inhibition percentage against extract concentration. Trolox was used as standard.

\subsubsection{Inhibition of lipid peroxidation using thiobarbituric acid-reactive} substances (TBARS)

Brains were obtained from pig (Sus scrofa) of body weight $\sim 150 \mathrm{~kg}$, dissected and homogenised in ice-cold Tris- $\mathrm{HCl}$ buffer (20 mM, pH 7.4) using a Polytron, to produce a 1:2 (w/v) brain tissue homogenate which was centrifuged at $3000 \mathrm{~g}$ for $10 \mathrm{~min}$. An aliquot $(0.1 \mathrm{~mL})$ of the supernatant was incubated with the 
different concentrations of the extracts $(0.03-1.00 \mathrm{mg} / \mathrm{mL} ; 0.2 \mathrm{~mL}$ ) in the presence of $\mathrm{FeSO}_{4}(10 \mu \mathrm{M} ; 0.1 \mathrm{~mL})$ and ascorbic acid $(0.1 \mathrm{mM} ; 0.1 \mathrm{~mL})$ at $37^{\circ} \mathrm{C}$ for $1 \mathrm{~h}$. The reaction was stopped by the addition of trichloroacetic acid $(28 \% \mathrm{w} / \mathrm{v}, 0.5 \mathrm{~mL})$, followed by thiobarbituric acid (TBA, $2 \%, \mathrm{w} / \mathrm{v}, 0.38 \mathrm{~mL}$ ), and the mixture was then heated at $80^{\circ} \mathrm{C}$ for $20 \mathrm{~min}$. After centrifugation at $3000 \mathrm{~g}$ for 10 min to remove the precipitated protein, the colour intensity of the malondialdehyde (MDA)-TBA complex in the supernatant was measured by its absorbance at $532 \mathrm{~nm}$. The inhibition ratio (\%) was calculated using the following formula:

Inhibition $\operatorname{ratio}(\%)=[(A-B) / A] \times 100$,

where $A$ and $B$ were the absorbance of the control and the compound solution, respectively. The extract concentration providing $50 \%$ lipid peroxidation inhibition $\left(E C_{50}\right)$ was calculated from the graph of TBARS inhibition percentage against extract concentration. Trolox was used as standard.

\subsection{Electrochemical assays to evaluate antioxidant activity}

\subsubsection{Sample preparation}

A lyophilised fine powder of plant flowers (20 mesh; $1 \mathrm{~g}$ ) was extracted with $50 \mathrm{~mL}$ methanol in the refrigerator $\left(\sim 4{ }^{\circ} \mathrm{C}\right)$ for $24 \mathrm{~h}$, in the dark and without stirring. After extraction, samples were filtered in a glass funnel through glass wool. For each sample, an aliquot of $10 \mathrm{~mL}$ of filtered extract was transferred to a vial containing $\mathrm{NaClO}_{4}$, so that the final concentration of support electrolyte was $0.1 \mathrm{M}$. Solutions were analysed immediately.

\subsubsection{Instrumentation}

Cyclic voltammetry (CV) and differential pulse voltammetry (DPV) measurements were performed on an Autolab PGSTAT 302 potentiostat/galvanostat (Metrohm Autolab B.V., Utrecht), using a closed standard three electrode cell. A glassy carbon electrode (MF-2012, $\phi=3.0 \mathrm{~mm}$; BASi, Lafayette, IN) was used as working electrode and $\mathrm{Pt}$ foil as counter electrode. All potentials refer to an $\mathrm{Ag} / \mathrm{AgCl} 3 \mathrm{M} \mathrm{KCl}(+207 \mathrm{mV}$ vs SHE) reference electrode (Metrohm). Prior to use, the working electrode was cleaned through physical, chemical and electrochemical treatment: (i) it was polished against a Master-Tex (Bühler Ltd., London, UK) polishing pad wetted with an aqueous suspension of $0.3-\mu \mathrm{m}$ alumina (Bühler), (ii) sonicated in $6 \mathrm{M} \mathrm{HCl}$ for $1 \mathrm{~min}$, and then in methanol, and (iii) submitted to an anodic current of $2.0 \mathrm{~V}$ for $60 \mathrm{~s}$. The electrode was thoroughly rinsed with deionised water and methanol between every step, and blotted dry. This is important because polyphenolic compounds tend to strongly adsorb at the surface of glassy carbon electrodes.

\subsubsection{Procedure}

All extracts and standard compounds were studied in methanolic $0.1 \mathrm{M} \mathrm{NaClO}_{4}$. All the solutions were analysed immediately after preparation and the electrochemical responses recorded after immersion of the glassy carbon electrode, to minimise adsorption of species onto the electrode surface prior to run. Cyclic voltammetry $(\mathrm{CV})$ was used to characterise the electrochemical responses between -0.5 and $+1.5 \mathrm{~V}$, at $100 \mathrm{mV} / \mathrm{s}$, whereas the antioxidant power was evaluated by differential pulse voltammetry (DPV), using the following operating conditions: $60 \mathrm{mV}$ pulse amplitude and $20 \mathrm{mV} / \mathrm{s}$ scan rate.

\subsubsection{Quantification}

A calibration curve was prepared by plotting the concentration of ascorbic acid solutions between 0.05 and $10.00 \mathrm{mg} / \mathrm{mL}$ against the current intensity of the respective DPV signals measured at peak maxima. This curve was found to be linear in the range $0.05-1.32 \mathrm{mg} / \mathrm{mL}$. The analytical signal of samples (current density) was measured between peak maxima and the baseline, defined as the tangent between the lowest and the highest potential valley. This current density was converted to equivalents of ascorbic acid $(\mathrm{mg} / \mathrm{mL})$, and expressed in terms of equivalents of ascorbic acid (AA) per gram of plant material (DW), assuming the total volume used in the extraction procedure $(50 \mathrm{~mL})$ and the sample weight. The sum of the values calculated at peak maxima for each electrochemical process was used to express the total electrochemical antioxidant power (TEAP) of the plant material.

\subsection{Statistical analysis}

The results are expressed as mean values \pm standard deviation (SD). The results were analysed using one-way analysis of variance, followed by Tukey's HSD Test with $\alpha=0.05$. This treatment was carried out using SPSS Version16.0 (Chicago, IL).

\section{Results and discussion}

\subsection{Phytochemicals and antioxidants}

The content in vitamins (tocopherols and ascorbic acid) and pigments (carotenoids and chlorophylls) of the three studied medicinal plants are given in Table 1 . Ascorbic acid was the most abundant vitamin ( $>1730 \mu \mathrm{g} / \mathrm{g} \mathrm{DW})$ and $\alpha$-tocopherol was the major tocopherol in all the samples $(>313 \mu \mathrm{g} / \mathrm{g}) ; F$. ulmaria was the richest sample in $\alpha$-tocopherol; its tocopherols profile is shown in Fig. 1. $\delta$-Tocopherol was not detected in S. nigra and was a minor compound in the other two plants. Flowers of F. ulmaria and C. multiflorus presented the highest content of ascorbic acid $(2700 \mu \mathrm{g} / \mathrm{g}$ and $2670 \mu \mathrm{g} / \mathrm{g}$, respectively) and tocopherols (497 and $483 \mu \mathrm{g} / \mathrm{g}$, respectively), without significant differences, $p<0.05$, between them. Kaack and Austed (1998) reported the quantification of ascorbic acid in fresh fruits of S. nigra $(60-250 \mu \mathrm{g} / \mathrm{g})$, but nothing is reported about the concentration of ascorbic acid or tocopherols in the flowers of the three studied plants.

Vitamin E (tocopherols) and vitamin C (ascorbic acid) are naturally-occurring antioxidant nutrients that play important roles in health by inactivating harmful free radicals produced through normal cellular activity and from various stressors (Chew, 1995). Cooperative interactions exist among vitamin $\mathrm{C}$ and vitamin $\mathrm{E}$; they interact synergistically at the membrane-cytosol interface to regenerate membrane-bound oxidised vitamin $\mathrm{E}$. The interac-

Table 1

Composition of medicinal plants in vitamins $(\mu \mathrm{g} / \mathrm{g} D W)$, pigments $(\mu \mathrm{g} / \mathrm{g} D W)$ and sugars $(\mathrm{mg} / \mathrm{g} \mathrm{DW})$ (mean $\pm \mathrm{SD} ; n=9$ ). In each row different letters mean significant differences $(p<0.05)$.

\begin{tabular}{lccc}
\hline Compound & Cytisus multiflorus & Filipendula ulmaria & Sambucus nigra \\
\hline$\alpha$-tocopherol & $348 \pm 17.5 \mathrm{~b}$ & $425 \pm 15.5 \mathrm{a}$ & $313 \pm 4.08 \mathrm{c}$ \\
$\beta$-tocopherol & $34.8 \pm 4.14 \mathrm{a}$ & $15.9 \pm 0.13 \mathrm{~b}$ & $8.12 \pm 0.71 \mathrm{c}$ \\
$\gamma$-tocopherol & $92.6 \pm 4.51 \mathrm{a}$ & $44.3 \pm 1.66 \mathrm{~b}$ & $2.89 \pm 0.18 \mathrm{c}$ \\
$\delta$-tocopherol & $7.63 \pm 0.46 \mathrm{~b}$ & $11.3 \pm 0.92 \mathrm{a}$ & \multicolumn{1}{c}{ nd } \\
Total tocopherols & $483 \pm 9.32 \mathrm{a}$ & $497 \pm 16.1 \mathrm{a}$ & $324 \pm 4.61 \mathrm{~b}$ \\
Ascorbic acid & $2670 \pm 12.6 \mathrm{a}$ & $2700 \pm 27.0 \mathrm{a}$ & $1730 \pm 4.79 \mathrm{~b}$ \\
$\beta$-carotene & $53.9 \pm 0.06 \mathrm{a}$ & $36.3 \pm 0.17 \mathrm{~b}$ & $18.4 \pm 0.05 \mathrm{c}$ \\
Lycopene & $11.3 \pm 0.04 \mathrm{a}$ & $6.18 \pm 0.08 \mathrm{~b}$ & $5.34 \pm 0.04 \mathrm{c}$ \\
Chlorophyll a & $60.3 \pm 0.05 \mathrm{~b}$ & $78.2 \pm 0.07 \mathrm{a}$ & $45.0 \pm 0.02 \mathrm{c}$ \\
Chlorophyll b & $51.6 \pm 0.10 \mathrm{a}$ & $46.7 \pm 0.20 \mathrm{~b}$ & $32.0 \pm 0.06 \mathrm{c}$ \\
Glucose & $42.7 \pm 1.40 \mathrm{a}$ & $13.1 \pm 0.61 \mathrm{c}$ & $32.3 \pm 0.66 \mathrm{~b}$ \\
Fructose & $69.3 \pm 2.71 \mathrm{a}$ & $19.8 \pm 0.65 \mathrm{c}$ & $26.6 \pm 0.96 \mathrm{~b}$ \\
Sucrose & $18.3 \pm 0.73 \mathrm{~b}$ & $11.3 \pm 0.44 \mathrm{c}$ & $24.7 \pm 0.26 \mathrm{a}$ \\
Trehalose & $7.62 \pm 0.98 \mathrm{~b}$ & $20.9 \pm 1.17 \mathrm{a}$ & $\mathrm{nd}$ \\
Total sugars & $138 \pm 5.82 \mathrm{a}$ & $65.1 \pm 0.53 \mathrm{c}$ & $83.6 \pm 0.92 \mathrm{~b}$
\end{tabular}

nd - not detected. 


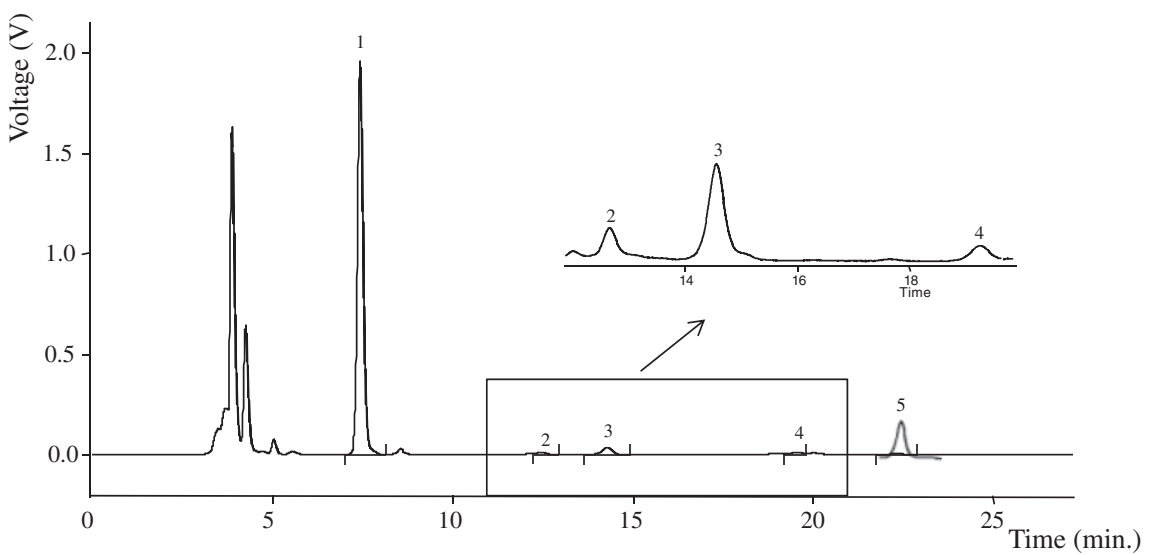

Fig. 1. Tocopherols profile of F. ulmaria. 1: $\alpha$-Tocopherol; $2: \beta$-tocopherol; $3: \gamma$-tocopherol; 4 : $\delta$-tocoferol; 5 : tocol (IS).

tions among these antioxidants are very important in protecting cells because the concentration of each antioxidant alone may not be adequate to effectively protect cells from lipid peroxidation (Chew, 1995; Nagaoka, Kakiuchi, Ohara, \& Mukai, 2007). The presence of both vitamins could explain the empirical uses of the studied plants in oxidative stress-related diseases as previously discussed.

Carotenoids and chlorophylls were found in all the studied medicinal plants, Table 1 . The concentrations of $\beta$-carotene (53.9 $\mu \mathrm{g} / \mathrm{g} \mathrm{DW})$, lycopene $(11.3 \mu \mathrm{g} / \mathrm{g})$ and chlorophyll b $(51.6 \mu \mathrm{g} /$ g) were higher in C. multiflorus flowers. F. ulmaria contained the highest levels of chlorophyll a $(78.2 \mu \mathrm{g} / \mathrm{g})$. Carotenoids are amongst nature's most widespread pigments and have also received substantial attention because of both their provitamin and antioxidant roles. The peroxyl radicals (ROO-) formed from lipids (especially polyunsaturated phospholipids) are very damaging to cells. The extensive systems of double bonds make carotenoids susceptible to attack by peroxyl radicals, resulting in the formation of inactive products (Rao \& Rao, 2007). Chlorophyll and its derivatives are also known to have antioxidant activity, being associated with reduced risks of diseases induced by free radicals, such as certain types of cancers. The function of chlorophyll in animals is suggested to be inhibition of lipid peroxidation and protection of mitochondria from oxidative damage induced by various free-radicals (Lanfer-Marquez, Barros, \& Sinnecker, 2005). Therefore, these pigments could be very important antioxidants.

The three wild medicinal plants contained glucose, fructose, sucrose and trehalose as main sugars (Table 1). Fructose predominates in $C$. multiflorus, trehalose was the most abundant sugar in
F. ulmaria and glucose predominates in S. nigra. C. multiflorus flowers revealed the highest total sugars content $(138 \mathrm{mg} / \mathrm{g} \mathrm{DW})$, with the highest levels of glucose $(42.7 \mathrm{mg} / \mathrm{g})$ and fructose $(69.3 \mathrm{mg} / \mathrm{g})$, both of them reducing sugars. The sugars profile of this sample is shown in Fig. 2. Veberic, Jakopic, Stampar, and Schmitzer (2009) reported the concentrations of individual sugars in fruits of $S$. nigra (68.5-104 mg/g FW) with fructose, glucose and sucrose as main sugars. Other authors described the levels of glucose $(2.02 \mathrm{~g} / \mathrm{L})$ and sucrose $(1.79 \mathrm{~g} / \mathrm{L})$ in concentrated juices of $S$. nigra fruits (Sadilova, Stintzing, Kammerer, \& Carle, 2009). Nonetheless, nothing is reported about their concentrations in any of the flowers studied herein.

The results for fatty acid composition, total saturated fatty acids (SFA), monounsaturated fatty acids (MUFA) and polyunsaturated fatty acids (PUFA) of the three wild medicinal plants are shown in Table 2. Twenty-four fatty acids were identified and quantified. The major fatty acids found were $\alpha$-linolenic acid (C18:3 n-3; 25$33 \%$ ) followed by linoleic acid (C18:2 n-6; 18-25\%) contributing to the prevalence of PUFA in all the samples. Some authors showed that linoleic acid, conjugated linoleic acid, and linoleic methyl ester have antioxidative activity and proposed this as a possible explanation for anticarcinogenic and antiatherogenic effects. Nevertheless, additional studies are necessary to show their free radical-scavenging activity in different radical systems and under physiological conditions, and to determine whether there is any link between their radical-scavenging properties and their biological effects (Fagali \& Catalá, 2008).

Palmitic acid was the most abundant SFA in all samples (11$18 \%)$. This fatty acid was the major compound found in pollen of

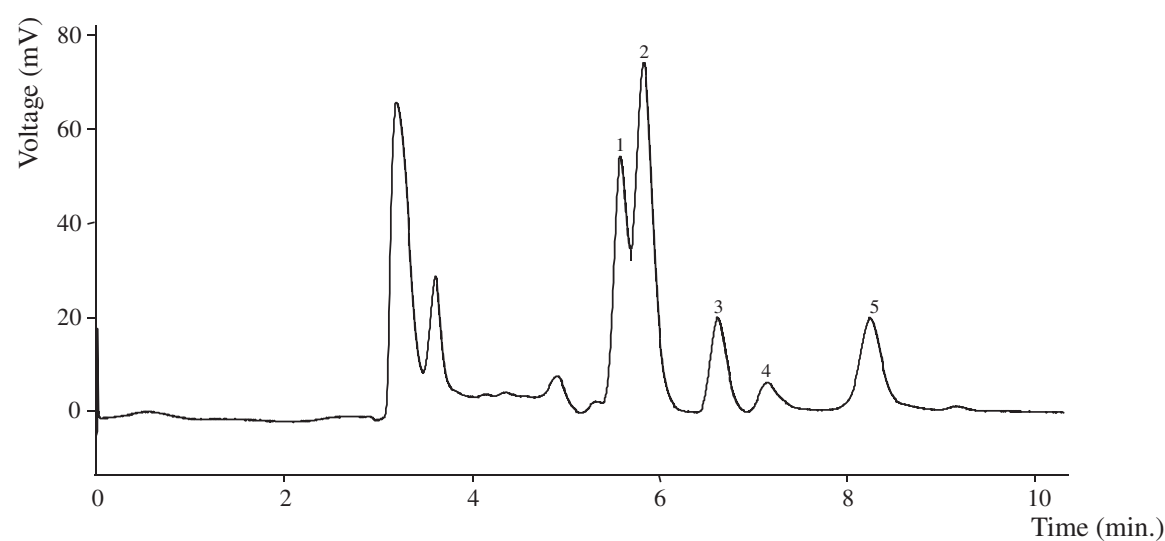

Fig. 2. Sugars profile of $C$. multiflorus. 1: Fructose; 2: glucose; 3: sucrose; 4: trehalose; 5: melezitose (IS). 
S. nigra (35.69\%), followed by C18:1 n-9 (14.26\%), C18:2 n-6 (12.79\%) and C18:3 n-3 (12.48\%) (Stránský, Valterová, \& Fiedler, 2001). Despite the similarities in the most abundant fatty acids in the pollen studied by those authors and in the flowers used in the present work, there are some differences in the levels found for each compound. The fatty acids profile of $S$. nigra flowers is shown in Fig. 3. As far as we know, this is the first report about the fatty acid composition in flowers of $C$. multiflorus and $F$. ulmaria.

Phenolic compounds are also important antioxidants found in the studied plants (45.6-92.7 mg GAE/g DW; Table 3); F. ulmaria flowers revealed the highest content in phenolics and flavonoids. This sample gave much higher total phenolic content than methanolic extracts of leaves of meadowsweet from Greece $(7.2 \mathrm{mg} / \mathrm{g}$ DW; Proestos, Boziaris, Kapsokefalou, \& Komaitis, 2008) and aerial parts from Finland (26.8 mg/g DW) (Kahkonen et al., 1999), and of aqueous extracts of aerial parts (flowers, stems and leaves) from Ireland submitted to different drying treatments $(110-119 \mathrm{mg} / \mathrm{g}$; Harbourne, Marete, Jacquier, and O'Riordan, 2009), temperatures (39-63 mg/g) and $\mathrm{pH}(43-57 \mathrm{mg} / \mathrm{g}$; Harbourne, Jacquier, and O'Riordan, 2009). Flavonoids have been extracted from meadowsweet leaves using hot aqueous ethanol (70\%) or methanol in a Soxhlet apparatus, and from meadowsweet flowers using hydroalcoholic solutions and these extracts were found to contain up to $6 \%$ total flavonoids. Leaves and flowers of $F$. ulmaria are known to contain phenolic acids (glycoside derivatives of salicylaldehyde and methyl salicylate), flavonols (glycosides of kaempferol and quercetin) and ellagitannins (rugosins and tellimagradins) (Calliste, Trouillas, Allais, Simon, \& Duroux, 2001; Fecka, 2009; Harbourne, Jacquier, \& O’Riordan, 2009; Harbourne, Marete, Jacquier, \& O'Riordan, 2009; Scheer \& Wichtl, 1987). Infusions of its flowers and strained decoctions of its underground rhizomes are highly recommended to treat pneumonia, flu, urinary tract infections, rheumatism and headache (Carvalho, 2010; Pardo de Santayana, 2008). In fact, meadowsweet has been traditionally used to treat various ailments due to its antipyretic, diuretic, analgesic and anti-inflammatory properties.

Elderberry, the berry of $S$. nigra (19.5 mg GAE/g FW; Wu, Gu, Prior, \& McKay, 2004) and particularly elderberry wine has been found to contain higher concentrations of phenolics than red wine (1753 mg GAE/L) (Rupasinghe \& Clegg, 2007). The anticarcinogenic and antioxidative effect of elderberry juice has also been attributed to the high content of anthocyanins and other flavonoids (Kaack \& Austed, 1998). A low-calorie juice cocktail (including elderberry) rich in anthocyanins was successfully used in a weight loss program in obese men (Chrubasik et al., 2008). Furthermore, the con-
Table 2

Composition (\%) of the medicinal plants in fatty acids (mean \pm SD; $n=9$ ). In each column different letters mean significant differences $(p<0.05)$.

\begin{tabular}{|c|c|c|c|}
\hline Fatty acid & $\begin{array}{l}\text { Cytisus } \\
\text { multiflorus }\end{array}$ & $\begin{array}{l}\text { Filipendula } \\
\text { ulmaria }\end{array}$ & Sambucus nigra \\
\hline C6:0 & $0.10 \pm 0.01$ & $2.16 \pm 0.11$ & $0.03 \pm 0.00$ \\
\hline C8:0 & $0.06 \pm 0.00$ & $0.19 \pm 0.01$ & $0.02 \pm 0.00$ \\
\hline C10:0 & $0.04 \pm 0.00$ & $0.06 \pm 0.00$ & $0.02 \pm 0.00$ \\
\hline $\mathrm{C} 12: 0$ & $0.33 \pm 0.00$ & $0.73 \pm 0.01$ & $0.14 \pm 0.00$ \\
\hline $\mathrm{C} 14: 0$ & $0.53 \pm 0.02$ & $10.05 \pm 0.53$ & $0.42 \pm 0.03$ \\
\hline C14:1 & $0.05 \pm 0.00$ & $0.11 \pm 0.01$ & $0.05 \pm 0.00$ \\
\hline C15:0 & $0.13 \pm 0.01$ & $0.12 \pm 0.00$ & $0.15 \pm 0.00$ \\
\hline C15:1 & nd & nd & $2.07 \pm 0.41$ \\
\hline C16:0 & $11.14 \pm 0.02$ & $12.22 \pm 0.03$ & $18.06 \pm 0.53$ \\
\hline C16:1 & $0.60 \pm 0.02$ & nd & $0.36 \pm 0.04$ \\
\hline $\mathrm{C} 17: 0$ & $0.37 \pm 0.02$ & $0.37 \pm 0.03$ & $0.28 \pm 0.02$ \\
\hline C18:0 & $4.09 \pm 0.02$ & $3.93 \pm 0.13$ & $2.02 \pm 0.17$ \\
\hline $\mathrm{C} 18: 1 \mathrm{n}-9 \mathrm{cis}$ & $6.59 \pm 0.76$ & $2.28 \pm 0.10$ & $11.93 \pm 0.16$ \\
\hline C18:2 n-6 cis & $24.31 \pm 0.28$ & $18.02 \pm 0.58$ & $24.64 \pm 0.49$ \\
\hline C18:3 n-6 & nd & $0.11 \pm 0.01$ & nd \\
\hline$C 18: 3 n-3$ & $32.49 \pm 1.11$ & $32.89 \pm 0.47$ & $25.43 \pm 1.73$ \\
\hline C20:0 & $3.21 \pm 0.08$ & $3.48 \pm 0.25$ & $1.26 \pm 0.10$ \\
\hline C20:1 cis & $0.47 \pm 0.02$ & $0.32 \pm 0.05$ & $0.81 \pm 0.02$ \\
\hline C20:2cis & $0.18 \pm 0.02$ & $0.06 \pm 0.00$ & nd \\
\hline $\begin{array}{l}\mathrm{C} 20: 3 n- \\
\quad 3+\mathrm{C} 21: 0\end{array}$ & $0.36 \pm 0.01$ & $1.10 \pm 0.05$ & $0.21 \pm 0.01$ \\
\hline $\mathrm{C} 20: 5 n-3$ & nd & $0.85 \pm 0.05$ & $0.57 \pm 0.03$ \\
\hline $\mathrm{C} 22: 0$ & $1.68 \pm 0.05$ & $2.53 \pm 0.09$ & $1.99 \pm 0.20$ \\
\hline$C 23: 0$ & $11.26 \pm 0.29$ & $4.35 \pm 0.01$ & $1.81 \pm 0.26$ \\
\hline $\mathrm{C} 24: 0$ & $2.07 \pm 0.04$ & $4.06 \pm 0.14$ & $7.74 \pm 1.21$ \\
\hline Total SFA & $34.98 \pm 0.33 b$ & $44.26 \pm 0.67 a$ & $33.92 \pm 1.47 b$ \\
\hline Total MUFA & $7.71 \pm 1.75 b$ & $2.71 \pm 0.16 c$ & $15.23 \pm 0.64 a$ \\
\hline Total PUFA & $57.34 \pm 1.38 a$ & $53.03 \pm 0.83 b$ & $50.85 \pm 2.11 b$ \\
\hline
\end{tabular}

nd - not detected.

Table 3

Extraction yields, content in phenolics and flavonoids, and antioxidant activity $\left(E C_{50}\right.$ values, $\mathrm{mg} / \mathrm{mL}$ ) of the medicinal plants (mean $\pm \mathrm{SD} ; n=9$ ). In each row different letters mean significant differences $(p<0.05)$.

\begin{tabular}{|c|c|c|c|}
\hline & $\begin{array}{l}\text { Cytisus } \\
\text { multiflorus }\end{array}$ & $\begin{array}{l}\text { Filipendula } \\
\text { ulmaria }\end{array}$ & $\begin{array}{l}\text { Sambucus } \\
\text { nigra }\end{array}$ \\
\hline Extraction yield (\%) & $36.3 \pm 3.27 a$ & $29.3 \pm 2.03 b$ & $37.7 \pm 2.12 \mathrm{a}$ \\
\hline Phenolics (mg GAE/g DW) & $45.6 \pm 3.29 c$ & $228 \pm 0.53 a$ & $92.7 \pm 4.66 b$ \\
\hline Flavonoids (mg CE/g DW) & $7.86 \pm 0.42 c$ & $62.4 \pm 4.83 a$ & $26.2 \pm 0.51 b$ \\
\hline DPPH-scavenging activity & $2.02 \pm 0.11 \mathrm{a}$ & $0.05 \pm 0.01 \mathrm{c}$ & $0.57 \pm 0.03 b$ \\
\hline Reducing power & $0.64 \pm 0.02 a$ & $0.06 \pm 0.00 c$ & $0.27 \pm 0.01 b$ \\
\hline $\begin{array}{l}\beta \text {-Carotene bleaching } \\
\text { inhibition }\end{array}$ & $0.35 \pm 0.01 \mathrm{a}$ & $0.09 \pm 0.01 c$ & $0.16 \pm 0.01 b$ \\
\hline TBARS inhibition & $0.30 \pm 0.02 \mathrm{a}$ & $0.05 \pm 0.00 c$ & $0.12 \pm 0.01 b$ \\
\hline
\end{tabular}

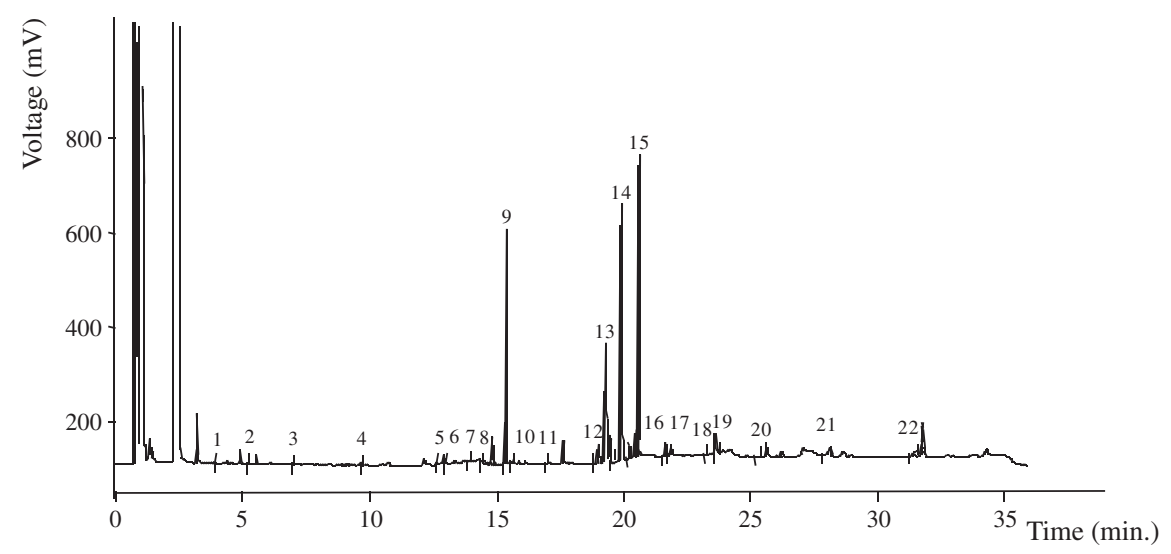

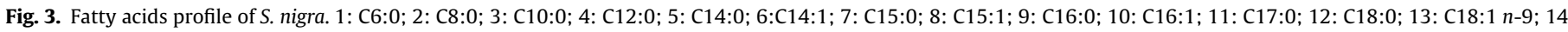
C18:2 n-6; 15: C18:3 n-3; 16: C20:0; 17: C20:1; 18: C20:3 n-3 + C21:0; 19: C20:5 n-3; 20: C22:0; 21: C23:0; 22: C24:0. 
sumption of elderberry juice induces a significant rise in plasma antioxidant capacity and a significant decrease in plasma malondialdehyde in vivo (Netzel et al., 2002, 2005).

Flowers of $S$. nigra have been found to contain hydroxycinnamic acids, mono- and di-caffeoylquinic acid derivatives, flavones and flavonol glycosides (Christensen, Kaack, \& Fretté, 2008; Dawidowicz, Wianowska, Gawdzik, \& Smolarz, 2003; Rieger, Müller, Guttenberger, \& Bucar, 2008). Elderflower is recommended by the German Commission E for upper respiratory tract infections for its secretolytic effect (Chrubasik et al., 2008). Its pharmacological properties result, among other things, from the presence of flavonoids (Dawidowicz, Wianowska, \& Baraniak, 2006). Furthermore, elderflower extracts are used as beverage and food flavourings (Veberic et al., 2009). Different European ethnobotanical surveys document that elder can satisfy several traditional needs (Carvalho, 2010; Neves, Matosa, Moutinho, Queiroz, \& Gomes, 2009; Parada, Carrió, Bonet, \& Vallès, 2009; Vallès, Bonet, \& Agelet, 2004). The flower heads are used in infusions to treat respiratory system affections, such as bronchitis, cough, and cold infections; they are also a very good tonic for diabetes, blood cleanser and stomachic. Externally, the decoctions are used in poultices to ease pain and reduce inflammation, or as an ointment to heal chilblains, burns and wounds. Sometimes elder infusions are seen as a panacea (Carvalho, 2010).

Cytisus sp. pl. have been found to contain C-glycosyl flavones (6"-O-acetylscoparin), flavonol glycosides (rutin, quercetin, kaempferol, isorhamnetin, quercitrin) and isoflavones (genistein, sarothamnoside) (Brum-Bousquet, Lallemand, Tillequin, Fougeras, \& Delaveau 1981; Viscardi, Reynaud, \& Raynaud,1984). The use of a dried flowers' infusion of C. multiflorus to control metabolic and endocrine system disorders (such as cholesterol and diabetes), hypertension, rheumatism and headache is widespread in Portugal (Carvalho, 2010; Pardo de Santayana et al., 2007).

\subsection{Antioxidant activity}

Due to the chemical diversity of antioxidant compounds present in natural samples, it is unrealistic to separate each antioxidant component and study it individually. In addition, levels of single antioxidants do not necessarily reflect their total antioxidant capacity because of the possible synergistic interactions among the antioxidant compounds in a food mixture (Magalhães, Segundo, Reis, \& Lima, 2008). Therefore, we evaluated the antioxidant properties of the entire extracts obtained from flowers of the three medicinal plants.

All the samples showed antioxidant activity in the order of F. ulmaria $>S$. nigra $>C$. multiflorus (Table 3). Flowers of $F$. ulmaria (meadowsweet) gave the lowest $E C_{50}$ values in all the assays (lower than $0.1 \mathrm{mg} / \mathrm{mL}$ ). Particularly for DPPH-scavenging activity assay, this studied sample showed better results $(50 \%$ at $0.047 \mathrm{mg} / \mathrm{mL}$ ) than flowering tops of $F$. ulmaria from France (35.0\% for water fraction and $59.4 \%$ for methanol fraction at $0.1 \mathrm{mg} / \mathrm{mL}$; Calliste et al., 2001). Dawidowicz et al. (2006) reported that flower extracts of $S$. nigra from Poland exhibited higher antioxidant activity (measured by DPPH-neutralising activity and $\beta$-carotene-bleaching inhibition assays) than its berries and leaves extracts.

Significantly negative linear correlations were established between the phenolics and flavonoids content, and $E C_{50}$ values of DPPH-scavenging activity $\left(y=-0.0093 x+2.015 ; r^{2}=0.735\right.$ for phenolics and $y=-0.0327 x+1.933 ; r^{2} 0.794$ for flavonoids; $p<0.001)$, reducing power $\left(y=-0.0028 x+0.668 ; r^{2}=0.820\right.$ for phenolics and $y=-0.0099 x+0.640 ; r^{2} 0.868$ for flavonoids; $p<0.001), \beta$-carotene bleaching inhibition $(y=-0.0012 x+0.353$; $r^{2}=0.740$ for phenolics and $y=-0.0044 x+0.342 ; r^{2} 0.800$ for flavonoids, $p<0.001)$ and TBARS inhibition $(y=-0.0012 x+0.297$; $r^{2} 0.715$ for phenolics and $y=-0.0041 x+0.287 ; r^{2} 0.777$ for flavonoids, $p<0.001)$. This proves that $F$. ulmaria with the highest phenols and flavonoids contents is the most efficient in antioxidant activity (with the lowest $E C_{50}$ values). The correlations were slightly more significant for flavonoids than for phenolics, and the highest determination coefficients were obtained for reducing power assay.

The cyclic voltammograms (CV) observed for the three flower extracts revealed two regions in the potential window under study (Fig. 4a). In the range between -0.5 and $+0.2 \mathrm{~V}$, samples were electrochemically silent, with only $S$. nigra showing a low intensity reduction process on the reverse scan at potentials below $0 \mathrm{~V}$. The oxidative current density started then to rise at potentials near $0.2 \mathrm{~V}$, showing maximum intensity around $0.6 \mathrm{~V}$, followed then by a second oxidation process around $1 \mathrm{~V}$. It is also possible to observe some other minor oxidation processes leading to wave broadening or shoulders. This seems to indicate the presence of several electroactive species in the extracts. Peak potentials for the different samples are presented in Table 4. F. ulmaria showed a first oxidation process (shoulder) at lower potentials than other samples. This could be explained due to the presence of more easily oxidisable species in this extract. Additionally, the second oxidation process, common to all samples, presents the highest current density in this plant. In fact, $F$. ulmaria showed the highest content in phenolics, flavonoids, total tocopherols and ascorbic acid (Tables 1-3). Moreover, it consistently showed stronger antioxidant activity as measured by DPPH, reducing power, $\beta$-carotene bleaching and TBARS methods (Table 3 ). This is in agreement with the expectation that samples with lower oxidation potentials and higher oxidative current densities should display higher antioxidant activities. Based on $\mathrm{CV}$, the electrochemical behaviour corroborated the greater antioxidant activity found for F. ulmaria; however, the comparison for S. nigra and C. multiflorus is somehow ambiguous since the peak

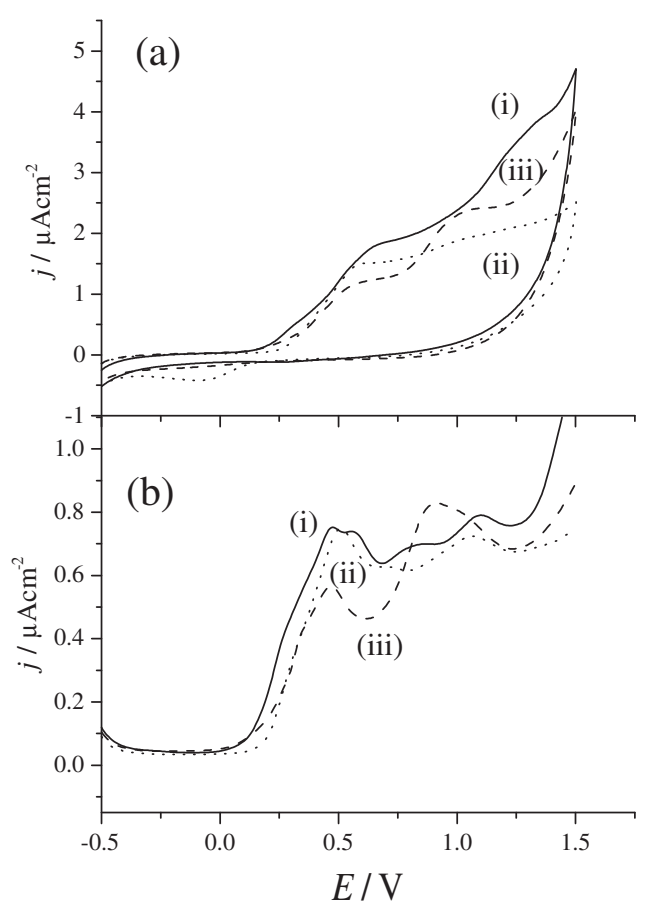

Fig. 4. Electrochemical responses for the sample extracts of (i) Filipendula ulmaria (ii) Sambucus nigra and (iii) Cytisus multiflorus in methanol/0.1 $\mathrm{M} \mathrm{NaClO}_{4}$ solutions, obtained with a glassy carbon electrode collected between -0.5 and $1.5 \mathrm{~V}$ (a) Cyclic voltammograms (first scan) at $100 \mathrm{mV} / \mathrm{s}$. (b) Differential pulse voltammograms obtained with $60 \mathrm{mV}$ pulse amplitude scanned at $20 \mathrm{mV} / \mathrm{s}$. 
Table 4

Peak potentials obtained for the electrochemical oxidation processes of the sample extracts (mean \pm SD; $n=6$ ).

\begin{tabular}{|c|c|c|c|c|c|c|}
\hline & \multicolumn{3}{|c|}{ Cyclic voltammetry (V) } & \multicolumn{3}{|c|}{ Differential pulse voltammetry (V) } \\
\hline & C. multiflorus & F. ulmaria & S. nigra & C. multiflorus & F. ulmaria & S. nigra \\
\hline Ep1 & - & $0.25 \pm 0.03$ & - & $0.35 \pm 0.02$ & $0.28 \pm 0.01$ & - \\
\hline Ep2 & $0.54 \pm 0.01$ & $0.63 \pm 0.01$ & $0.58 \pm 0.00$ & $0.46 \pm 0.01$ & $0.46 \pm 0.00$ & $0.50 \pm 0.00$ \\
\hline Ep3 & $0.99 \pm 0.01$ & $1.23 \pm 0.02$ & $1.01 \pm 0.01$ & - & $0.58 \pm 0.01$ & - \\
\hline Ep4 & - & - & - & $0.91 \pm 0.04$ & $0.82 \pm 0.01$ & $0.71 \pm 0.00$ \\
\hline Ep5 & - & - & - & $1.02 \pm 0.01$ & $1.11 \pm 0.04$ & $1.06 \pm 0.00$ \\
\hline Ep6 & - & - & - & $1.20 \pm 0.00$ & $1.30 \pm 0.01$ & - \\
\hline
\end{tabular}

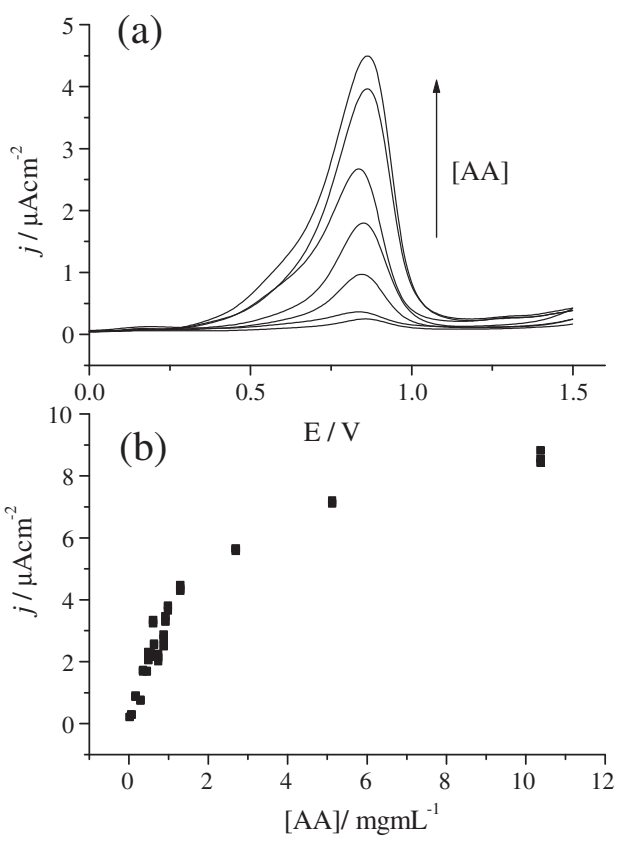

Fig. 5. (a) Differential pulse voltammograms obtained for $0.05-1.02 \mathrm{mg} / \mathrm{mL}$ ascorbic acid in methanol/0.1 M NaClO 4 solutions, obtained with a glassy carbon electrode between -0.5 and $1.5 \mathrm{~V}$, with $60 \mathrm{mV}$ pulse amplitude at $20 \mathrm{mV} / \mathrm{s}$. (b) Variation of the oxidation peak height, obtained by DPV, with ascorbic acid concentration.

potential is slightly lower for the latter, but S. nigra presents a higher current density.

The differential pulse voltammogram (DPV), Fig. 4b, follows a pattern similar to that of $\mathrm{CV}$ : a first region between -0.5 and $+0.2 \mathrm{~V}$ with no significant electrochemical activity, followed by an increase in oxidative current density with maxima around 0.6 and $1 \mathrm{~V}$. In this second region of DPV, however, it was possible to resolve more oxidation processes compared to $\mathrm{CV}$, with F. ulmaria displaying at least six distinct oxidation waves, whereas $C$. multiflorus and S. nigra showed five and three processes, respectively. Again,

Table 5

Total electrochemical antioxidant power (TEAP) expressed as ascorbic acid equivalents per gram of sample (DW; mean $\pm S D ; n=6)$, calculated from the DPV experiments.

\begin{tabular}{llll}
\hline & \multicolumn{3}{l}{ Electrochemical antioxidant power (expressed mgAA/g DW) } \\
\cline { 2 - 4 } & Cytisus multiflorus & Filipendula ulmaria & Sambucus nigra \\
\hline Ep1 & $2.19 \pm 0.16$ & $2.71 \pm 0.10$ & - \\
Ep2 & $2.13 \pm 0.65$ & $4.37 \pm 1.02$ & $6.71 \pm 0.53$ \\
Ep3 & $2.81 \pm 0.61$ & $3.43 \pm 0.81$ & - \\
Ep4 & - & $1.60 \pm 0.72$ & $3.48 \pm 0.42$ \\
Ep5 & $2.06 \pm 0.31$ & $1.47 \pm 0.72$ & $2.01 \pm 0.17$ \\
Ep6 & $0.46 \pm 0.00$ & $0.16 \pm 0.09$ & - \\
TEAP & $9.64 \pm 2.73$ & $13.7 \pm 4.48$ & $12.2 \pm 1.65$ \\
\hline
\end{tabular}

F. ulmaria showed a rise in current density at lower potentials than other samples. In terms of intensity it is C. multiflorus that shows the lowest current density for the common oxidation process at $0.5 \mathrm{~V}$, with the other two samples presenting a similar maximum value. This profile is not standard for the entire voltammogram, with the oxidative current density of $C$. multiflorus surpassing that of F. ulmaria at potentials around $0.9 \mathrm{~V}$.

In order to quantify the electrochemical antioxidant activity of samples we compared the current density of all oxidation peaks (peak height) with that of ascorbic acid (AA), which shows an irreversible oxidation peak around $0.86 \mathrm{~V}$ in methanol solutions containing $0.1 \mathrm{M} \mathrm{NaClO}_{4}$. Fig. $5 \mathrm{a}$ and $\mathrm{b}$ show the DPV voltammograms and the variation of peak current density plotted against AA concentration, respectively, where a linear correlation was found in the range $0.05-1.02 \mathrm{mg} / \mathrm{mL}$. This allows the expression of the contribution of each oxidation process to the electrochemical antioxidant activity in terms of equivalents of ascorbic acid.

Table 5 presents the quantitative results for all the resolved oxidation peaks obtained from DPV for the three samples under study. F. ulmaria shows, at lower oxidation potential, the most intense antioxidant processes; however, we cannot exclude the possible contribution of other oxidation process to the antioxidant activity. In fact, the capability for the sample to act as oxidative protector arises from the existence of easily oxidised species (low oxidation potential) and their amount, as well as from the presence of other less oxidisable species, providing that the substance to be protected has a higher oxidation potential. To account for the contributions of all species, we expressed the sum of AA equivalents as total electrochemical antioxidant power, TEAP. The calculated TEAP values were significantly lower for $C$. multiflorus, as found with the other antioxidant assays, but similar for F. ulmaria and S. nigra, suggesting that, for these species, the presence of the easily oxidised species mentioned above could make the difference.

\section{Conclusions}

Flowers of F. ulmaria, S. nigra and C. multiflorus were analysed for their phytochemical composition, and antioxidant activities were evaluated based of chemical, biochemical and electrochemical assays. The overall antioxidant activity of samples was found to vary in order F. ulmaria $>S$. nigra $>C$. multiflorus, irrespective of the method employed. These results were found to be in agreement with their content in antioxidants, especially total phenolics, flavonoids and ascorbic acid. This suggests that the electrochemical methods such as CV and DPV employed in this study are suitable for fast and inexpensive screening, profiling and quantification of antioxidant activity in complex plant matrices. These methods may become portable and enable rapid in-field analysis. Moreover, they are free from laborious sample preparation, use a minimum of reagents because they are based on an intrinsic property of the analyte (electroactive) and are applicable to non-transparent samples (Blasco et al., 2005).

These results also indicate there may be a basis for the ethnopharmacological use of these wild medicinal plants, related to their 
antioxidant and phytochemical composition. As such, that the studied extracts could be suitable for incorporation into functional beverages or products with potential anti-inflammatory and other health-promoting properties related to oxidative stress.

\section{Acknowledgements}

The authors are grateful to the Foundation for Science and Technology (FCT, Portugal) for financial support to the research centre CIMO. L. Barros thanks FCT, POPH-QREN and FSE for her grant (SFRH/BPD/4609/2008). L. Cabrita thanks Soraia Falcão for assistance with the electrochemical experiments.

\section{References}

Barros, L., Falcão, S., Baptista, P., Freire, C., Vilas-Boas, M., \& Ferreira, I. C. F. R. (2008). Antioxidant activity of Agaricus sp. Mushrooms by chemical, biochemical and electrochemical assays. Food Chemistry, 111, 61-66.

Blasco, A. J., Rogerio, M. C., González, M. C., \& Escarpa, A. (2005). "Electrochemical Index" as a screening method to determine "total polyphenolics" in foods: A proposal. Analytical Chimica Acta, 539, 237-244.

Brum-Bousquet, M., Lallemand, J. Y., Tillequin, F., Fougeras, P., \& Delaveau, P. (1981). Isolation and properties of sarothamnoside, a novel isoflavone glycoside from various Sarothamnus species. Planta Medica, 43, 367-374.

Calliste, C.-A., Trouillas, P., Allais, D.-P., Simon, A., \& Duroux, J. L. (2001). Free radical scavenging activities measured by electron spin resonance spectroscopy and B16 cell antiproliferative behaviors of seven plants. Journal of Agricultural and Food Chemistry, 49, 3321-3327.

Camejo-Rodrigues, J., Ascensão, L., Bonet, M. À., \& Vallès, J. (2003). An ethnobotanical study of medicinal and aromatic plants in the Natural Park of "Serra de São Mamede" (Portugal). Journal of Ethnopharmacology, 89, 199-209.

Carvalho, A.M. (2010). Plantas y sabiduría popular del Parque Natural de Montesinho. Un estudio etnobotánico en Portugal. Biblioteca de Ciencias 35. Madrid: Consejo Superior de Investigaciones Científicas.

Chevion, S., Chevion, M., Chock, M. B., \& Beecher, G. R. (1999). Antioxidant capacity of edible plants: Extraction protocol and direct evaluation by cyclic voltammetry. Journal of Medicinal Food, 2, 1-10.

Chew, B. P. (1995). Antioxidant vitamins affect food animal immunity and health. Journal of Nutrition, 125, 1804S-1808S.

Christensen, L. P., Kaack, K. V., \& Fretté, X. (2008). Selection of elderberry (Sambucus nigra L.) genotypes best suited for the preparation of elderflower extracts rich in flavonoids and phenolic acids. European Food Research and Technology, 27, 293-305.

Chrubasik, C., Maier, T., Dawid, C., Torda, T., Schieber, A., Hofmann, T., et al. (2008). An observational study and quantification of the actives in a supplement with Sambucus nigra and Asparagus officinalis used for weight reduction. Phytotherapy Research, 22, 913-918.

Conforti, F., Sosa, S., Marrelli, M., Menichini, F., Statti, G. A., Uzunov, D., et al. (2008). In vivo anti-inflammatory and in vitro antioxidant activities of Mediterranean dietary plants. Journal of Ethnopharmacology, 116, 144-151.

Cosio, M. S., Buratti, S., Mannino, S., \& Benedetti, S. (2006). Use of an electrochemical method to evaluate the antioxidant activity of herb extracts from the Labiatae family. Food Chemistry, 97, 725-731.

Dawidowicz, A. L., Wianowska, D., \& Baraniak, B. (2006). The antioxidant properties of alcoholic extracts from Sambucus nigra L. (antioxidant properties of extracts). Lebensmittel-Wissenschaft und-Technologie, 39, 308-315.

Dawidowicz, A. L., Wianowska, D., Gawdzik, J., \& Smolarz, D. H. (2003). Optimization of ASE conditions for the HPLC determination of rutin and isoquercitrin in Sambucus nigra L.. Journal of Liquid Chromatography and Related Technologies, 26, 2381-2397.

Fagali, N. \& Catalá, A. (2008). Antioxidant activity of conjugated linoleic acid isomers, linoleic acid and its methyl ester determined by photoemission and $\mathrm{DPPH}$ techniques. Biophysical Chemistry, 137, 56-62.

Fecka, I. (2009). Qualitative and quantitative determination of hydrolysable tannins and other polyphenols in herbal products from meadowsweet and dog rose. Phytochemical Analysis, 20, 177-190.

Ferreira, I. C. F. R., Barros, L., \& Abreu, R. M. V. (2009). Antioxidants in wild mushrooms. Current Medicinal Chemistry, 16, 1543-1560.

Frankel, E. N., \& Finley, J. W. (2008). How to standardize the multiplicity of methods to evaluate natural antioxidants. Journal of Agricultural and Food Chemistry, 56, 4901-4908.

Gutteridge, J. M., \& Halliwell, B. (2000). Free radicals, antioxidants in the year 2000. A historical look to the future. Annuals of New York Academic Sciences, 899, 136-147.

Halliwell, B. (1996). Antioxidants in human health and disease. Annual Reviews of Nutrition, 16, 33-50.

Harbourne, N., Jacquier, J. C., \& O'Riordan, D. (2009). Optimisation of the aqueous extraction conditions of phenols from meadowsweet (Filipendula ulmaria $\mathrm{L}$.) for incorporation into beverages. Food Chemistry, 116, 722-727.
Harbourne, N., Marete, E., Jacquier, J. C., \& O’Riordan, D. (2009). Effect of drying methods on the phenolic constituents of meadowsweet (Filipendula ulmaria) and willow (Salix alba). Lebensmittel-Wissenschaft und-Technologie, 42 1468-1473.

Kaack, K., \& Austed, T. (1998). Interaction of vitamin C and flavonoids in elderberry (Sambucus nigra L.) during juice processing. Plant Foods for Human Nutrition, 52, 187-198.

Kahkonen, M. P., Hopia, A. I., Vuorela, H. J., Rauha, J. P., Pihlaja, K., Kujala, T. S., et al. (1999). Antioxidant activity of plant extracts containing phenolic compounds. Journal of Agricultural and Food Chemistry, 47, 3954-3962.

Kilmartin, P. A., Zou, H., \& Waterhouse, A. L. (2001). A cyclic voltammetry method suitable for characterizing antioxidant properties of wine and wine phenolics. Journal of Agricultural and Food Chemistry, 49, 1957-1965.

Lanfer-Marquez, U. M., Barros, R. M. C., \& Sinnecker, P. (2005). Antioxidant activity of chlorophylls and their derivatives. Food Research International, 38, 885-891.

Litescu, S. C., \& Radu, G. L. (2000). Estimation of the antioxidative properties of tocopherols. European Food Research and Technology, 211, 218-221.

López, V., Akerreta, S., Casanova, E., García-Mina, J. M., Cavero, R. Y., \& Calvo, M. I. (2007). In vitro antioxidant and anti-rhizopus activities of Lamiaceae herbal extracts. Plant Foods for Human Nutrition, 62, 151-155.

Magalhães, L. M., Segundo, M. A., Reis, S., \& Lima, J. L. F. C. (2008). Methodological aspects about in vitro evaluation of antioxidant properties. Anaytical Chimica Acta, 613, 1-19.

Nagaoka, S., Kakiuchi, T., Ohara, K., \& Mukai, K. (2007). Kinetics of the reaction by vitamin $\mathrm{E}$ is regenerated which natural by vitamin. Chemistry and Physics of Lipids, 146, 26-32.

Netzel, M., Strass, G., Herbst, M., Dietrich, H., Bitsch, R., Bitsch, I., et al. (2005). The excretion and biological antioxidant activity of elderberry antioxidants in healthy humans. Food Research International, 38, 905-910.

Netzel, M., Strass, G., Kaul, C., Bitsch, I., Dietrich, H., \& Bitsch, R. (2002). In vivo antioxidative capacity of a composite berry juice. Food Research International, 35, 213-216.

Neves, J. M., Matosa, C., Moutinho, C., Queiroz, G., \& Gomes, L. R. (2009). Ethnopharmacological notes about ancient uses of medicinal plants in Trásos-Montes (northern of Portugal). Journal of Ethnopharmacology, 124, 270-283.

Parada, M., Carrió, E., Bonet, M. A., \& Vallès, J. (2009). Ethnobotany of the Alt Empordà region (Catalonia, Iberian Peninsula): Plants used in human traditional medicine. Journal of Ethnopharmacology, 124, 609-618.

Pardo de Santayana, M. (2008). Estudios etnobotánicos en Campoo (Cantábria). Biblioteca de Ciencias 33. CSIC: Madrid.

Pardo de Santayana, M., Tardio, J., Blanco, E., Carvalho, A. M., Lastra, J. J., San Miguel E., et al. (2007). Traditional knowledge of wild edible plants used in the northwest of the Iberian Peninsula (Spain and Portugal): A comparative study. Journal of Ethnobiology and Ethnomedicine, 3, 27-37.

Prior, R. L., Wu, X. L., \& Schaich, K. (2005). Standardized methods for the determination of antioxidant capacity and phenolics in foods and dietary supplements. Journal of Agricultural and Food Chemistry, 53, 4290-4302.

Proestos, C., Boziaris, I. S., Kapsokefalou, M., \& Komaitis, M. (2008). Natural antioxidant constituents from selected aromatic plants and their antimicrobial activity against selected pathogenic microorganisms. Food Technology and Biotechnology, 46, 151-156.

Rao, A. V., \& Rao, L. G. (2007). Carotenoids and human health. Pharmacological Research, 55, 207-216.

Rieger, G., Müller, M., Guttenberger, H., \& Bucar, F. (2008). Influence of altitudinal variation on the content of phenolic compound in wild populations of Calluna vulgaris, Sambucus nigra, and Vaccinium myrtillus. Journal of Agricultural and Food Chemistry, 56, 9080-9086.

Rupasinghe, H. P. V., \& Clegg, S. (2007). Total antioxidant capacity, total phenolic content, mineral elements, and histamine concentrations in wines of different fruit sources. Journal of Food Composition and Analysis, 20, 133-137.

Sadilova, E., Stintzing, F. C., Kammerer, D. R., \& Carle, R. (2009). Matrix dependent impact of sugar and ascorbic acid addition on color and anthocyanin stability of black carrot, elderberry and strawberry single strength and from concentrate juices upon thermal treatment. Food Research International, 42, 1023-1033.

Scheer, T., \& Wichtl, M. (1987). On the occurrence of kaempferol-4'-O-beta-Dglucopyranoside in Filipendula ulmaria and Allium cepa. Planta Medica, 53, 573-574.

Stránský, K., Valterová, I. \& Fiedler, P. (2001). Nonsaponifiable lipid components of the pollen of elder (Sambucus nigra L.). Journal of Chromatography A, 936, $173-181$.

Valko, M., Leibfritz, D., Moncol, J., Cronin, M. T., Mazur, M., \& Telser, J. (2007). Free radicals and antioxidants in normal physiological functions and human disease. International Journal of Biochemistry and Cell Biology, 39, 44-84.

Vallès, J., Bonet, M. A., \& Agelet, A. (2004). Ethnobotany of Sambucus nigra L. In Catalonia (Iberian peninsula): The integral exploitation of a natural resource in mountain regions. Economic Botany, 58, 456-469.

Veberic, R., Jakopic, J., Stampar, F., \& Schmitzer, V. (2009). European elderberry (Sambucus nigra L.) rich in sugars, organic acids, anthocyanins and selected polyphenols. Food Chemistry, 114, 511-515.

Viscardi, P., Reynaud, J., \& Raynaud, J. (1984). A New isoflavone glycoside from the flowers of Cytisus scoparius Link. (Leguminasae). Pharmazie, 39, 781.

Wu, X., Gu, L., Prior, R. L., \& McKay, S. (2004). Characterization of anthocyanins and proanthocyanidins in some Cultivars of Ribes, Aronia, and Sambucus and their antioxidant capacity. Journal of Agricultural and Food Chemistry, 52, 7846-7856. 